\title{
Structure Force Analysis for Clay Inclined Wall Dam of Duhu Reservoir Dongyu $\mathrm{Ji}^{\mathrm{a}}$

\author{
Hunan Urban Construction College, Xiangtan, Hunan Province 411101, P.R. China \\ ahnjdy@126.com
}

Keywords: Duhu reservoir, Clay inclined wall dam, Finite element method, Force analysis

\begin{abstract}
In this paper, finite element analysis is proceeded for clay inclined wall dam of Duhu reservoir. Deducing variation law of the dam's stress and displacement in construction process and operational process. The analytic results are shown: clay inclined wall dam of Duhu reservoir is reasonable structure, and every index meets the requirements for design.
\end{abstract}

\section{Introduction}

Duhu reservoir is located Cixi county in Zhejiang province. The basin area that is controlled by reservoir is $20 \mathrm{~km}^{2}$, hub buildings is make by dam, spillway, delivery tunnel and power station. The dam is clay inclined wall dam, dam high is $17.5 \mathrm{~m}$, dam length is $480 \mathrm{~m}$, dam crest width is $4 \mathrm{~m}$, dam bottom width is $83 \mathrm{~m}$, gradient of upstream face is $1: 2.5$, gradient of downstream face is $1: 2$, the foundation of dam is gravel layer. Reservoir's normal storage level is $14 \mathrm{~m}$, design level is 15.3 $\mathrm{m}$, flood level is $16.1 \mathrm{~m}$.

\section{Calculation Model}

Model Parameters. Clay inclined wall dam of Duhu reservoir adopts clay, elastic modulus $\mathrm{E}_{1}=45 \mathrm{MPa}^{[1]}$, Poisson ratio $\mu_{1}=0.31$, dry density $\gamma_{1}=15 \mathrm{kN} / \mathrm{m}^{3}$. Strata of dam site is gravel layer, elastic modulus $\mathrm{E}_{2}=16 \mathrm{GPa}$, Poisson ratio $\mu_{2}=0.28$.

Model Elements. Clay inclined wall dam and bedrock structure model is divided by eight nodes isoparametric block element. The element is often applied to three-dimensional model of entity structure, it has plasticity, creep, expansion, stress rigidization, large deformation and large strain characteristics. The element has eight nodes, each node has three translational degree of freedoms ${ }^{[2]}$.

Model Sizes. Universal finite element calculation software is adopted, three-dimensional finite element simulative analysis for clay inclined wall dam and bedrock of Duhu reservoir is proceeded. Calculation model simulation range is listed below, calculation model along the river is $203 \mathrm{~m}$, transverse of the river is $20 \mathrm{~m}$, vertical direction is $97.5 \mathrm{~m}$. The simulation range of whole calculation model is $203 \mathrm{~m} \times 20 \mathrm{~m} \times 97.5 \mathrm{~m}$. Element division of dam and bedrock is shown in Fig.1.

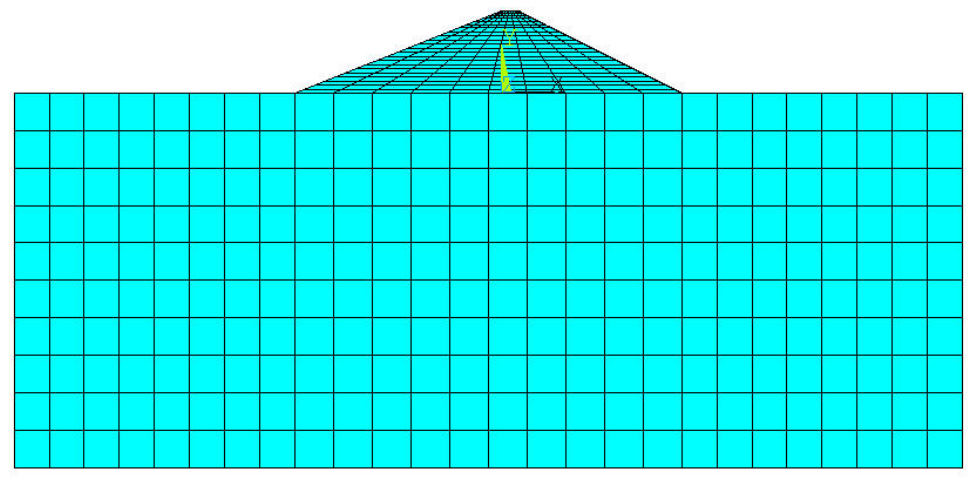

Fig.1 Element division of dam and bedrock

Calculation Cases. Considering mechanical characteristics of dam structure in construction and operating process ${ }^{[3]}$, researching five calculation cases as follows. Case 1 , dam weight(construction condition); case 2, dam weight, normal storage level, tail water level and sediment pressure(operating condition); case 3, dam weight, design level, tail water level and sediment 
pressure(operating condition); case 4, dam weight, flood level, tail water level and sediment pressure(operating condition); case 5, dam weight, design level, tail water level, sediment pressure and earthquake effect(operating condition).

\section{The Dam Structure Analysis}

Analysis Paths. In order to analyzing clay inclined wall dam of Duhu reservoir, two calculation paths are selected in the middle section of clay inclined wall dam. Path 1 , choosing one calculation point every $6.8 \mathrm{~m}$ from dam bottom to dam crest along earth dam's upstream face. Path 2, choosing one calculation point every $5.6 \mathrm{~m}$ from dam bottom to dam crest along earth dam's downstream face.

Stress Analysis. Calculation point's first principal stress value on the analysis path of clay inclined wall dam's middle section under various cases are listed in the table 1.

Table 1. Calculation point's first principal stress value on clay inclined wall dam's analysis path under various cases $(\mathrm{kPa})$

\begin{tabular}{cccccccccc}
\hline \multicolumn{2}{c}{ Calculation Point } & (1) & (2) & (3) & (4) & (5) & (6) & (7) & (8) \\
\hline \multirow{2}{*}{ Case 1 } & Path 1 & 1.99 & -10.86 & -11.26 & -9.42 & -6.82 & -4.83 & -3.09 & -0.95 \\
& Path 2 & -0.38 & -12.65 & -13.07 & -10.50 & -7.66 & -5.54 & -3.50 & -1.09 \\
\multirow{2}{*}{ Case 2 } & Path 1 & -33.19 & -53.93 & -45.36 & -34.61 & -21.73 & -8.66 & -3.07 & -0.95 \\
& Path 2 & -3.61 & -12.70 & -13.16 & -10.71 & -8.02 & -5.71 & -3.53 & -1.08 \\
\multirow{2}{*}{ Case 3 } & Path 1 & -34.49 & -58.46 & -50.66 & -40.01 & -27.67 & -15.12 & -3.63 & -0.95 \\
& Path 2 & -4.22 & -12.72 & -13.20 & -10.82 & -8.17 & -5.77 & -3.55 & -1.08 \\
\multirow{2}{*}{ Case 4 } & Path 1 & -35.19 & -61.01 & -53.93 & -43.29 & -31.19 & -19.07 & -8.77 & -0.95 \\
& Path 2 & -4.63 & -12.74 & -13.23 & -10.91 & -8.28 & -5.81 & -3.56 & -1.08 \\
\multirow{2}{*}{ Case 5 } & Path 1 & -17.47 & -51.35 & -46.98 & -36.27 & -24.14 & -12.37 & -3.69 & -1.00 \\
& Path 2 & -9.64 & -11.97 & -12.69 & -10.64 & -8.08 & -5.55 & -3.36 & -1.01 \\
\hline
\end{tabular}

We can see from table 1, under various cases, calculation point's first principal stress on the dam's analysis path are basically compressive stress. Stress values of two calculation paths are relatively closed under case 1 , this is mainly because the gradients of clay inclined wall dam's upstream face and downstream face are differ not quite, so stress values are relatively closed under dam weight. Under other cases, compressive stress values of clay inclined wall dam's upstream face are larger, this is mainly because the gradient of clay inclined wall dam's upstream face is gentler, dam produced larger compressive stress under water pressure, and compressive stress values are larger at the dam bottom.

Because case 3 is common condition of dam in operating process, case 5 is serious condition of dam in operating process. We obtain clay inclined wall dam's contour maps of first and third principal stress under case 3 and case 5, contour maps are shown from Fig.2 to Fig.5.

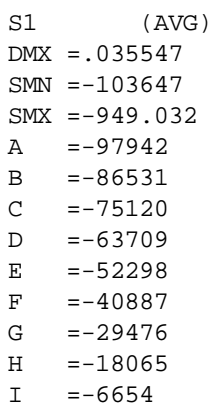

Fig.2 Contour map of first principal stress under case $3(\mathrm{~Pa})$ 


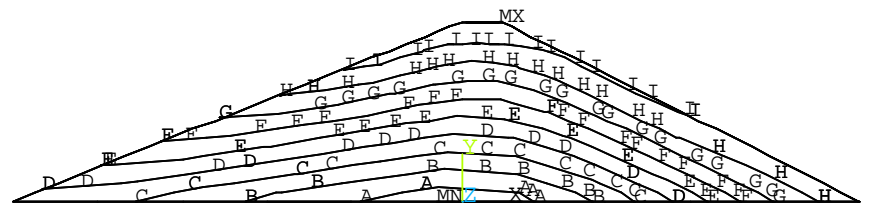

$$
\begin{aligned}
& \text { S3 } \quad(A V G) \\
& \text { RSYS }=0 \\
& \text { DMX }=.035547 \\
& \text { SMN }=-232275 \\
& \text { SMX }=-16178 \\
& \text { A }=-220270 \\
& B \quad=-196259 \\
& \text { C }=-172248 \\
& \text { D }=-148237 \\
& \text { E }=-124227 \\
& F \quad=-100216 \\
& \text { G }=-76205 \\
& H \quad=-52195 \\
& \text { I }=-28184
\end{aligned}
$$

Fig.3 Contour map of third principal stress under case $3(\mathrm{~Pa})$

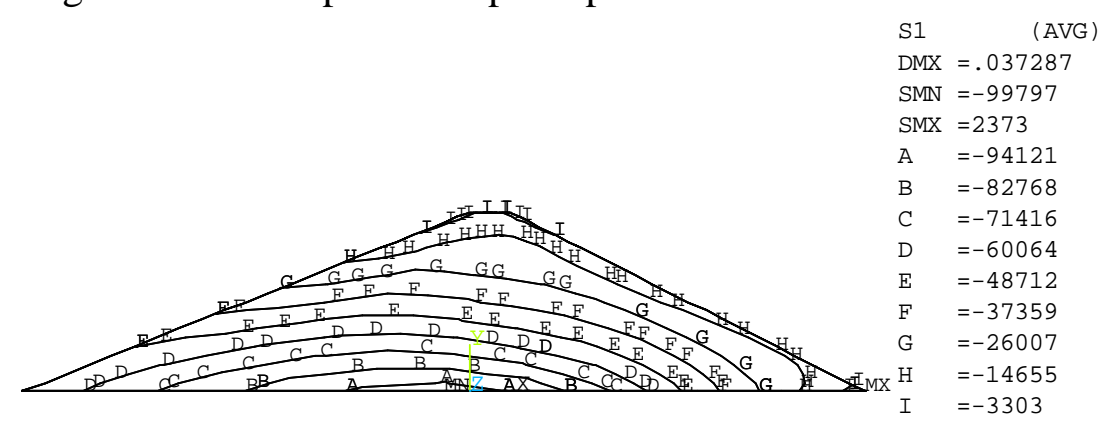

Fig.4 Contour map of first principal stress under case 5 ( $\mathrm{Pa})$

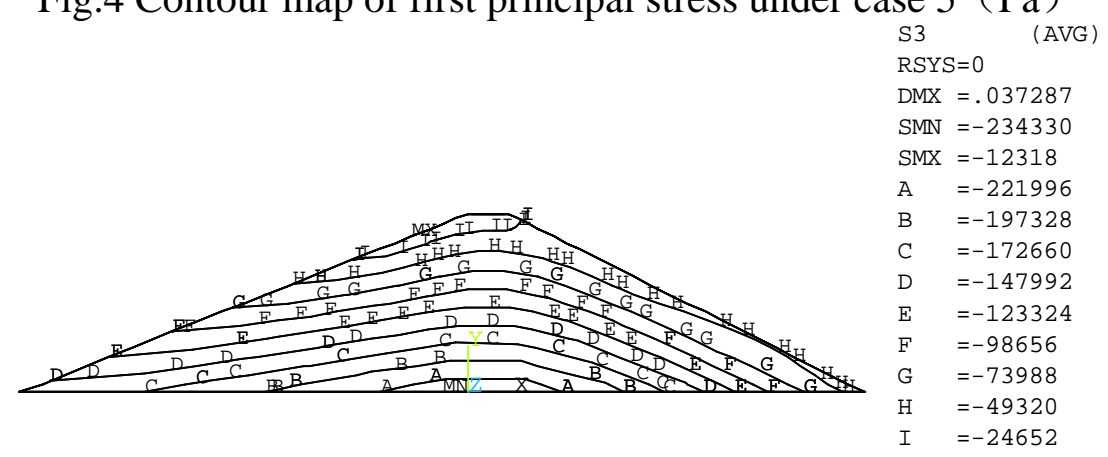

Fig.5 Contour map of third principal stress under case 5 ( $\mathrm{Pa}$ )

We can see from Fig.2 to Fig.5, clay inclined wall dam's first and third principal stress is compressive stress under case 3 and case 5. And the dam's first and third principal stress is layer distribution, compressive stress values of dam's bottom are larger, compressive stress values of dam's top are smaller. This is mainly because the dam weight and water pressure effect together, so producing such stress distribution law. Because the gradients of clay inclined wall dam's upstream face and downstream face are gentle, earthquake has a small impact on stress distribution, it leds to tensile stress of the dam increment slightly.

Deformation Analysis. In order to analysing deformation of clay inclined wall dam of Duhu reservoir, getting calculation point's horizontal and vertical displacement values on the analysis path of clay inclined wall dam's middle section under various cases. Now displacement values of analysis path 1 under case 1 , case 3 and case 5 are listed in the table 2 .

We can see from table 2, under case 1 , horizontal displacement of clay inclined wall dam is smaller, but vertical displacement of clay inclined wall dam is larger, and vertical displacement of clay inclined wall dam increases gradually from dam bottom to dam crest. This is mainly compression deformation of clay inclined wall dam and bedrock under the dam's weight. The dam bottom's vertical displacement is $0.19 \mathrm{~mm}$, it is bedrock's compression deformation value under the dam's weight. Under case 3 and 5, the dam's vertical displacement is similar, but horizontal displacement is vary greatly. This shows earthquake action impact on clay inclined wall dam's vertical displacement is puny, but it impact on clay inclined wall dam's horizontal displacement is marked. 
Table 2. Calculation point's horizontal and vertical displacement values on the analysis path 1 of clay inclined wall dam under case 1,3 and $5(\mathrm{~mm})$

\begin{tabular}{|c|c|c|c|c|c|c|c|c|c|}
\hline \multicolumn{2}{|c|}{ Calculation Point } & (1) & (2) & (3) & (4) & (5) & (6) & (7) & (8) \\
\hline \multirow{2}{*}{ Case 1} & $\begin{array}{c}\text { Horizontal } \\
\text { displacement }\end{array}$ & 0.06 & -0.66 & -1.93 & -2.70 & -2.10 & -2.48 & 1.00 & 0.50 \\
\hline & $\begin{array}{c}\text { Vertical } \\
\text { displacement }\end{array}$ & -0.19 & -1.04 & -3.60 & -7.79 & -13.95 & -22.40 & -30.21 & -35.67 \\
\hline \multirow{2}{*}{ Case3 } & $\begin{array}{c}\text { Horizontal } \\
\text { displacement }\end{array}$ & 0.11 & 3.81 & 4.97 & 4.76 & 4.13 & 3.74 & 3.57 & 2.90 \\
\hline & $\begin{array}{c}\text { Vertical } \\
\text { displacement }\end{array}$ & -0.69 & -6.37 & -11.76 & -16.79 & -21.49 & -26.35 & -30.77 & -35.17 \\
\hline \multirow{2}{*}{ Case 5} & $\begin{array}{c}\text { Horizontal } \\
\text { displacement }\end{array}$ & 0.15 & 4.53 & 7.22 & 8.90 & 10.19 & 11.45 & 12.26 & 12.04 \\
\hline & $\begin{array}{c}\text { Vertical } \\
\text { displacement }\end{array}$ & -0.68 & -6.35 & -11.70 & -16.69 & -21.38 & -26.27 & -30.73 & -35.16 \\
\hline
\end{tabular}

\section{Conclusion}

From the above, Duhu reservoir adopts clay inclined wall dam is economic and reasonable, the dam's stress is basically compressive stress, stress values can meet strength requirements. The dam's weight impact on clay inclined wall dam's displacement is very marked, it should strengthen control, improving construction quality, the dam can meet requirements, structure is safe and reliable.

\section{References}

[1] G.X. Li: Advanced Soil Mechanics(Tsinghua University Press, China 2005)(in Chinese)

[2] X.CH. Wang, M. SH: Finite Element Method Basic Principle and Numerical Method(Tsinghua University Press, China 1997)(in Chinese)

[3] SD 266-88: Technical Code for Grouting of Earth Dam(China Water Conservancy and Hydropower Press, China 1988)(in Chinese) 